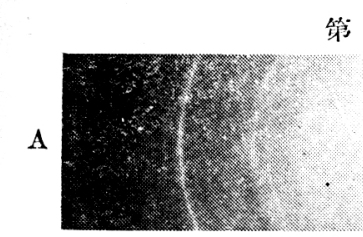

第
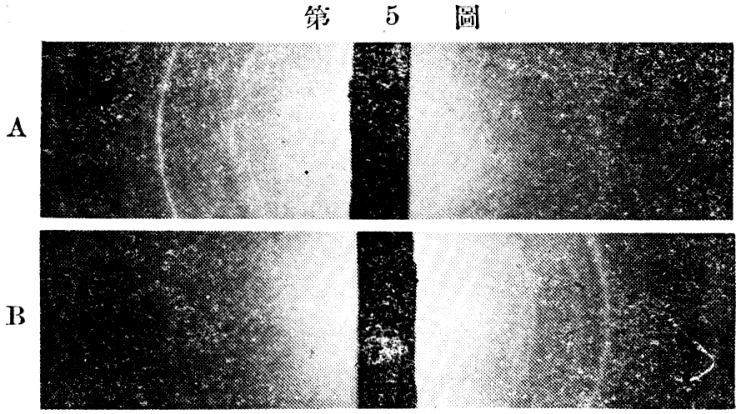

第 6 圖
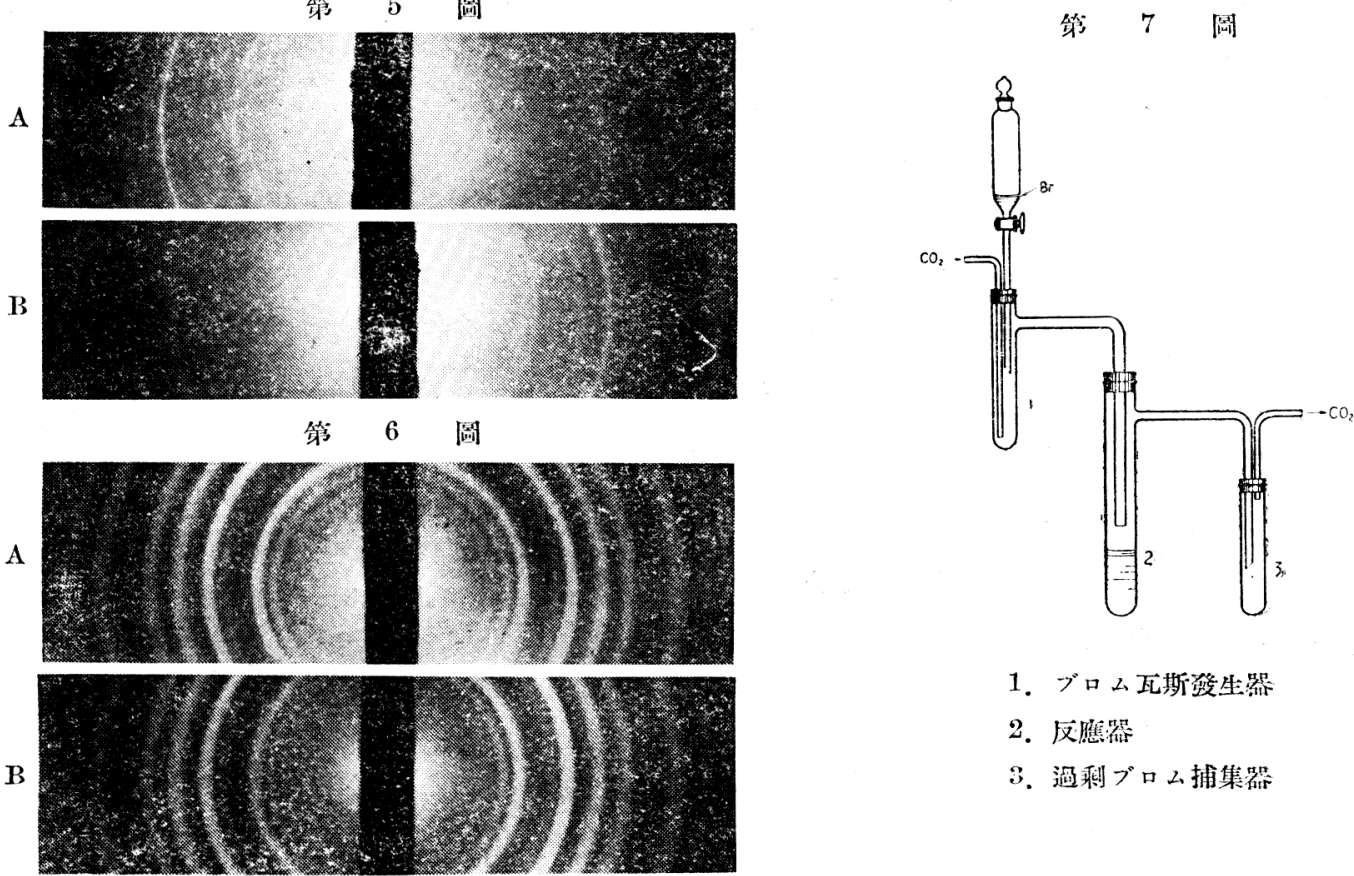
1.ブロム瓦斯發生器
2. 反應器
3. 過剩プロム捕集器

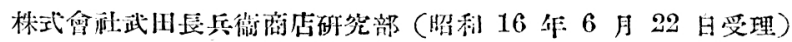

\title{
60. 6,8-ヂオキシテトラリソの合成研究
}

\section{三小孝造 和触 趿 阿部泰夫 太田武八郎}

著者等は暴にテトラリンヒフールの變化に就て研究中, 偶々 5,7-Dibrom-6,8-dioxytetralin 合成の必要に迫られた。 從來の交硐を步獵するに，本品の原料たる 6,8-Dioxytetralin の合成に關しては實に詳細を極めた G. Schroeter1)の

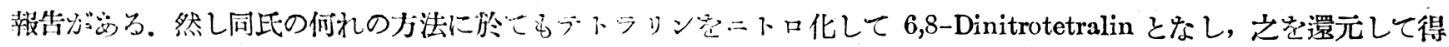

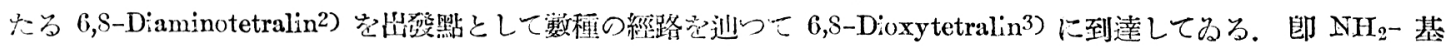

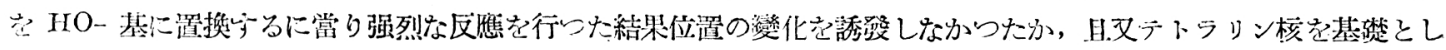

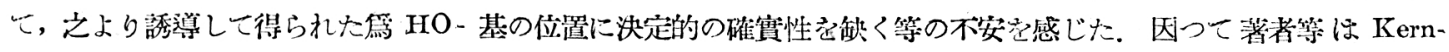
synthese によりて之合成し，G. Schroeter の所謂 6,8-Dioxytetralin (Tetraloresorein) の样浩さ再確認しょうと企。 劃し下記 A, B 及び C の法法試みた。

〔A〕 Nargund, Dalal 法4) で合成した $\beta$-(2,4-Dimethoxybenzoyl)-propionsäure (I) 究 Clemmensen-Martin 法

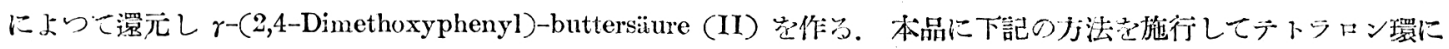
閉環させようとした。

a) r-(2,4-Dimethoxyphenyl)-buttersïure (II) にチオニルクロリド或は五監化橉を作用させてクロリドとなし， ニトロベンゾールを溶媒として監化アルミニウムの助による環形成を種々の條件下に試みたが，常に分解反應が起つ て不成功に終つた。

b) $\gamma$-(2,4-Dimethoxy phenyl)-buttersüure（II）のトルオール溶液に無水燐酸を抈へ，加熱して脫水反應を行ひ，

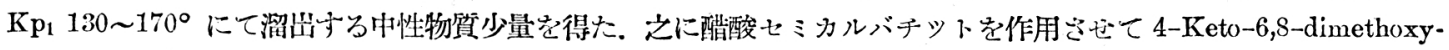
tetralin の Semicarbazon ( $\mathrm{Zp} 223^{\circ}$ ) (III) 極めて少許を得た. 上記䨘驗によりて明かな如く，(II）の $\mathrm{C}_{3}$ 估に何等

1) Schroeter: Per. 71, 1052 (1938). 2) Schroeter: Ann. 426, 78, 89 (1921). 3) Schroeter: Ber. 71, 1054 (1988). 4) Nargund, Dalal : J. Indian Chem. Suc. 14, 406 (1987). 
置換基がない爲, $\mathrm{C}_{6}$ 位の水素は活性甚だそしく, 從つて $\mathrm{C}_{6}$ 位の反應は極めて困難である. 因つて本法の邆行を中 止した.

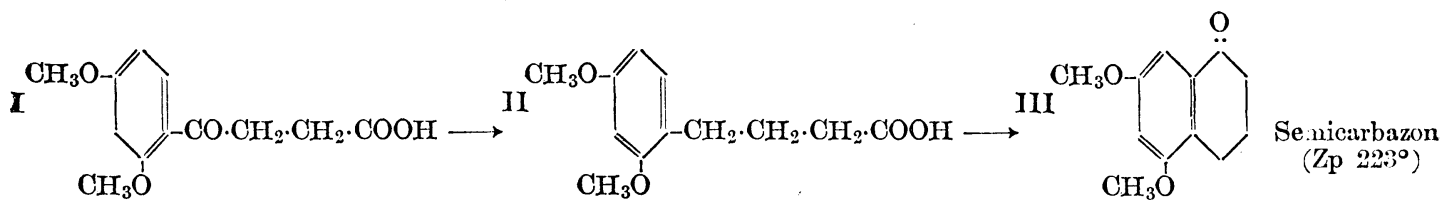

〔B〕閉環反應の起るべき炭素に對してパラ位置に置換基を有する $\gamma$-3,5-Dimethoxyphenylbuttersüure を合成し， 之にりき閉環を試みんと企てた.

a) 先ゔ $\gamma$-3,5-Dimethoxyphenylbuttersïure 苍合成する目的で, 3,5-Dimethoxybenzoylchlorid5) 党 Acetylbernsteinsäurediäthylester 5$)$ と作用させて $\alpha$-Acetyl- $\alpha$-(3,5-dimethoxybenzoyl)-bernsteinsüurediäthylester5) となし, 之 に脫アセチルと脫炭酸反應を行ひ，3,5-Dimethoxybenzoylpropionsäure 艺得ようとした．曾て Furukawa7)は 3,5Dimethoxybenzoylacetessigester $10 \%$ アンモニア水で醶化してアセチル基を除去し 3,5-Dimethoxybenzoylessigester 得たと報告してるる. 因つて著者等も此例に做ひ $\alpha$-Acetyl- $\alpha$-(3,5-dimethoxybenzoyl)-bernsteinsïurediäthylester (IV) の脫アセチル化を試夕た。然るに豫期に反して脫アセチル化は起らず 3,5-Dimethoxybenzoyl 基

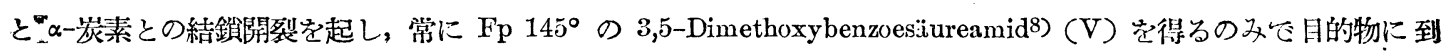
達し得なかつた。即脫アセチル反應が 3,5-Dimethoxybenzoylacetessigester に於て可能で岕り(IV)に於て不可能て あることは, 3,5-Dimethoxybenzoyl 基が結合してるる炭素の第 2 級と第 3 級との相違に山るものと考へられ極め て興味要る閣題で岁る。

IV
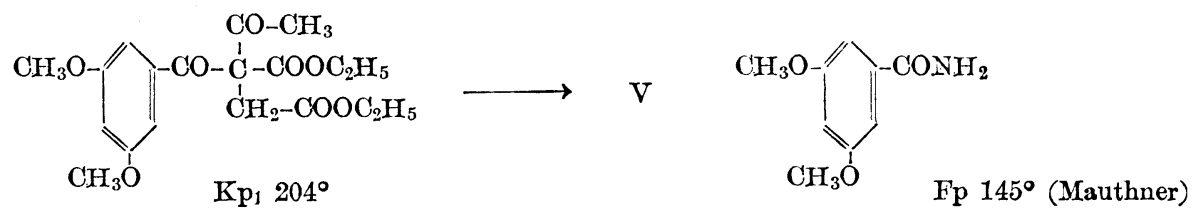

b) Mauthner 法による 3,5-Dimethoxybenzoylessigester9)に Bromessigester を作用させて得た K $\mathrm{p}_{2} 206$ 208ㅇ

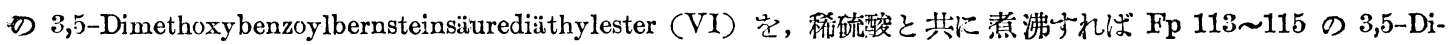
methoxybenzoylpropionsäure (VII) भ゙得られる。此を Clemmensen 法或は Clemmensen-Martin 法にて還元する 飞 buttersäure を得ることが出來なからた。前項の 2,4-Dimethoxybenzoylpropionsäure のみならず, 其他の Benzoylpropionsäure 誘導體及び $\gamma$-Phenylbutyrolacton が極めて容易に還元せられて對應する Phenylbuttersäure 誘導體と なる事實 ${ }^{10)}$ 對比して，本例がラクトン化するのみでそれ以上還元が進行しないことは實に興味要りと考へる・此問 題は後日解決を待ち议めて報告しょうと思ら。

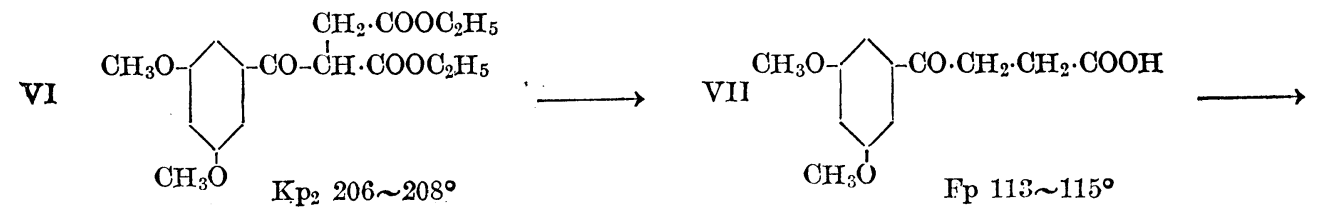<smiles>COC1CC(C)CC(CC(=O)OC(C)C)C1</smiles>

5) Mauthner: J. prakt. Chem. 87, 405 (1913).

6) Fichter, Pfister: Ber. 37, 1997 (1094). 7) Furukawa: Sci. Papers. Inst. Phys. Chem. Research (Tokyo) 26, 183 (1934-1935). prakt. Chem. 87, 403 (1913).

9) Mauthner: J. prakt. Chem. 107, 104 (1924).

8) Mauthner: J. Am. Chem. Soc. 58, 1438 (1936).

10) Martin : J. 
〔C〕4-Keto-6,7,8-trimethoxytetralin (IX) のイソアミルアルコール溶液にナトリリムを作用せしめて 6,8-D方 methoxytetralin (XII) となし, 次で脫メチル化を行ひ 6,8-Dioxytetralin $\left(\mathrm{XII}^{\prime}\right)$ そ得る方法さ試夕て終に目的物に 到達した。

先づ Mitter 及で De の法で合成した 4-Keto-6,8-dimethoxy-8-hydroxytetralin11) をヌチル化して Fp 770の 4-Keto-6,7,8-trimethoxytetralin (IX) となし, Clemmensen-Martin 法によつて還元し, Fp 42.5゚の 6,7,8-Tri-

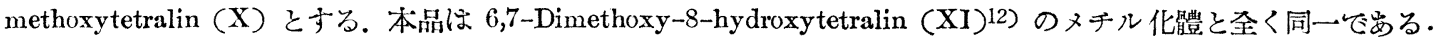

双て H. Thoms 敒び W. Siebeling13) の所說によれば, Pyrogalloltrimethyläther 誘導鳢の中央に在る Methoxyl 基は，之に對ナる パラ位置換基の存否に關係なく發生機水素によりて䮠逐される筈で学る。因りて著者等は上記 6,7,8-Trimethoxytetralin の埸合に於ても同樣に中央の Methoxyl 基の驅逐が可能で岁ららと豫想し，本物質のアル コールヌはイソアミルアルコール溶液に金屬ナトリウムを作用させたところ所期の 6,S-Dimethoxytetralin を得るに 至らなかつた．よつて朝比奈敎授14)による高級オルチン同族體の製造法に從ひ， $\mathrm{C}_{7}$ 位に對してパラ位に相當する $\mathrm{C}_{4}$ 位にケトン基を有广る上記 4-Keto-6,7,8-trimethoxytetralin (IX) のイソアミルアルコール溶液に，同一澴元法 を 施しケトン基の還元と $\mathrm{C}_{7}$ 位の Methoxyl 基離脫とを一擧に行つて目的の 6,8-Dimethoxytetralin (Tetraloresorcindimethyläther)15) (XII) に到達与ること艺得た。次て 5,S-Dimethoxytetralin をヨード水素酸と水㳻酸との混合液

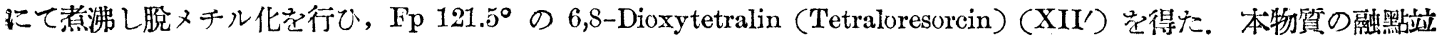
でに監化鐵，クロール不灰による是色反應等 G. Schroeter の Tetraloresorcin に全く一致方る. 然し本品の Diacetat

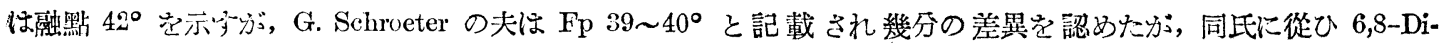
aminotetralin から作つた Tetraloresorcin と混融して全く同一物質であることを確認した。

以上の成績により G. Schroeter お 6,8-Dioxytetralin ほ著者等の Kernsynthese によつて水酸基つ位置に誤りな きこと碓定した次第で岕。

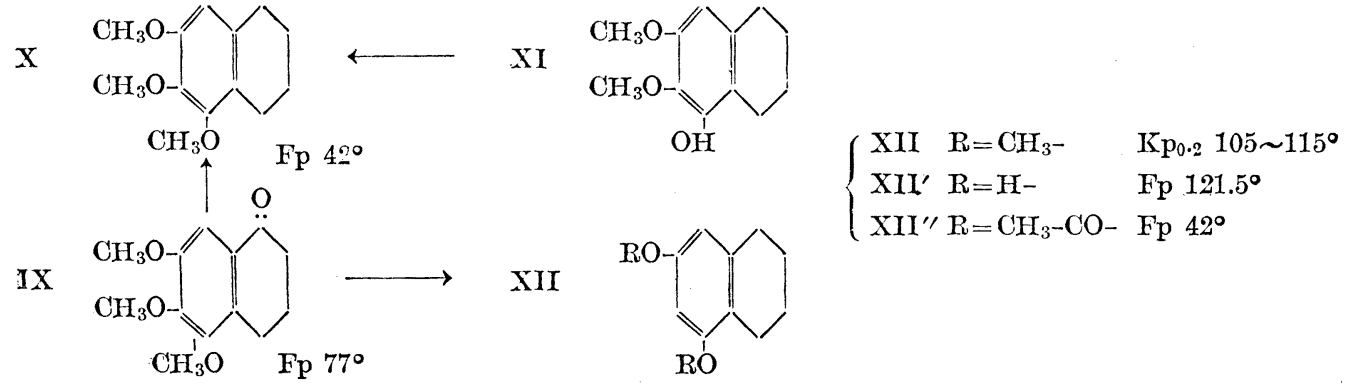

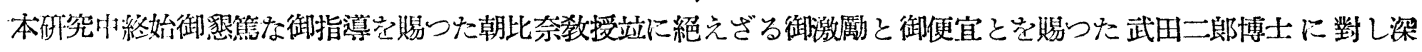
揕なる感謝の意さ表し，且多數の分析を擔當せられたる笠原，今井，數田の諸君に深謝与る。

\section{1) 2,4-Dimethoxyphenylbuttersäure (II)}

\section{實 驗之部}

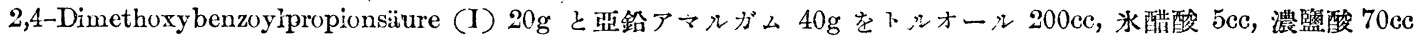

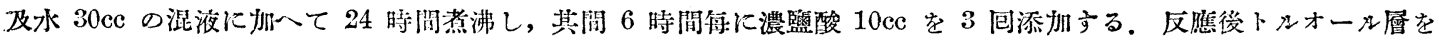
分取し，水洗乾燥後トルオーシを溜去し，殘渣を減烈蒸溜に附し， $\mathrm{Kp}_{1} 178 \sim 185^{\circ}$ の溜分を集める。本品を暫時放置

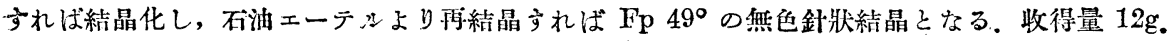

試料 $3.6350 \mathrm{mg}$ : $\mathrm{CO}_{2} 8.560 \mathrm{mg}, \mathrm{H}_{2} \mathrm{O} 2.230 \mathrm{mg}$.

$$
\mathrm{C}_{12} \mathrm{H}_{16} \mathrm{O}_{4} \text { 訫算值 } \quad \mathrm{C} \quad 64.29, \quad \mathrm{H} \text { 7.14. 實驗值 } \quad \mathrm{C} \quad 64.22, \quad \mathrm{H} \quad 6.86 \text {. }
$$

\section{2) 4-Keto-6,8-dimethoxytetralin $の$ Semicarbazon (III)}

11) Mitter, De: J. Indian Chem. Soc. 16, 40 (1939). (1939). 13) Thoms: Ber. 44, 2134 (1911). Ber. 71, 1055 (1938).
12) Mitter, De: J. Indian. Chem. Soc. 16, 41 14) Asahina: Ber. 69, 1643 (1936). 15) Schroeter : 


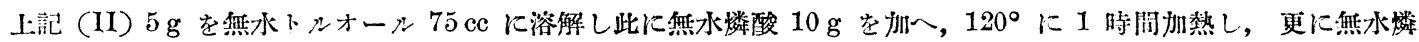

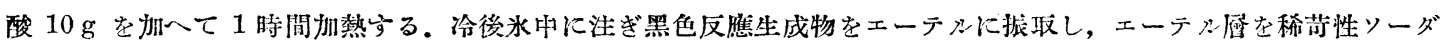

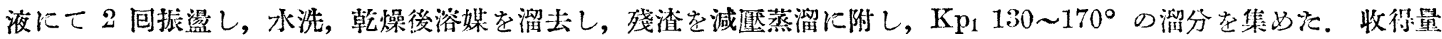

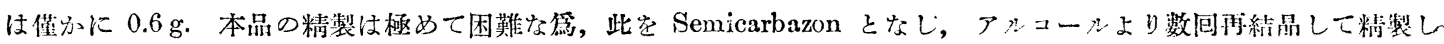

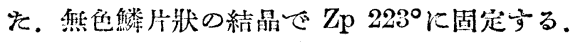

訪料 $3.750 \mathrm{mg}$ : $\mathrm{CO}_{2} 8.135 \mathrm{mg}, \mathrm{H}_{2} \mathrm{O} 2.130 \mathrm{mg}$.一試料 $2.830 \mathrm{mg}$ : $\mathrm{N}_{2} 0.374 \mathrm{cs}\left(15^{\circ}, 769 \mathrm{~mm}\right)$.

$$
\begin{array}{llllllll}
\mathrm{C}_{3} \mathrm{H}_{17} \mathrm{O}_{3} \mathrm{~N}_{3} & \text { 詁算值 } & \mathrm{C} & 59.28, & \mathrm{H} & 6.51, & \mathrm{~N} & 15.97 . \\
& \text { 鲟驗值 } & \mathrm{C} & 59.16, & \mathrm{H} & 6.36, & \mathrm{~N} & 15.85 .
\end{array}
$$

3) $a$-Acety1-a-(3,5-dimethoxybenzoy1)-bernsteinsäurediäthylester (IV)

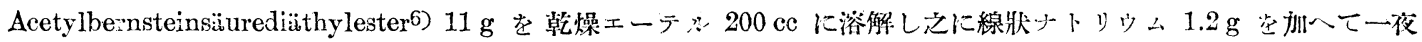

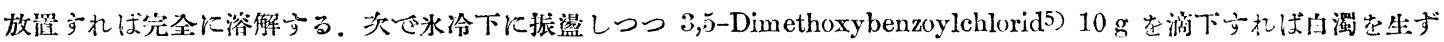

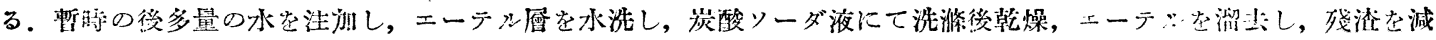
潄蒸溜に附して $\mathrm{Kp}_{1} 204^{\circ}$ の部分 (IV) を捕集する。無色粘稠なる液體.

的料 $3.660 \mathrm{mg}$ : $\mathrm{CO}_{2} 8.055 \mathrm{mg}, \mathrm{H}_{2} \mathrm{O} 2.095 \mathrm{mg}$.
$\mathrm{C}_{19} \mathrm{H}_{24} \mathrm{O}_{8}$ 許算值
C 60.00, H 6.32 .
實驗值
C 60.02, H 6.40 .

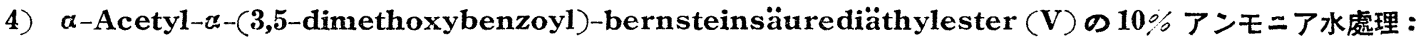

\section{3,5-Dimethoxybenzamid (IV) の生成}

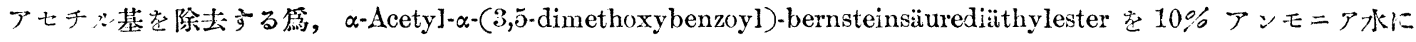

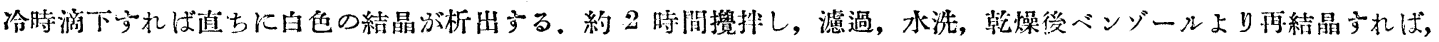
Fp 14万̄ำ色針狀の結晶となる，本品は元素分析の結果 F. Mauthner の 8,5-Dimethoxybenzamid8) (V) に合致 方る。

試料 $3.615 \mathrm{mg}$ : $\mathrm{CO}_{2} 7.915 \mathrm{mg}, \mathrm{H}_{2} \mathrm{O} 1.985 \mathrm{mg}$.一試料 $3.560 \mathrm{mg}$ : $\mathrm{N}_{2} 0.218 \mathrm{cc}\left(13^{\circ}, 771 \mathrm{~mm}\right)$.

$$
\begin{array}{llllllll}
\mathrm{C}_{9} \mathrm{H}_{11} \mathrm{O}_{3} \mathrm{~N} & \text { 訫算值 } & \mathrm{C} & 59.66, & \mathrm{H} & 6.06, & \mathrm{~N} & 7.74 . \\
& \text { 實驗值 } & \mathrm{C} & 59.71, & \mathrm{H} & 6.14, & \mathrm{~N} & 7.42 .
\end{array}
$$

\section{5) a-(3,5-Dimethoxybenzoyl)-bernsteinsäurediäthylester (VI)}

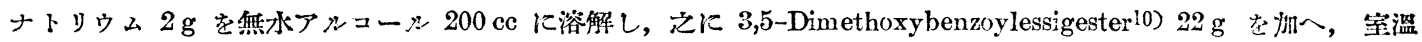

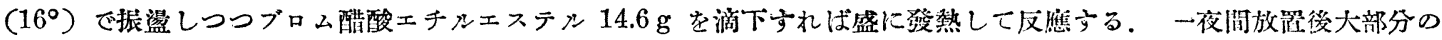

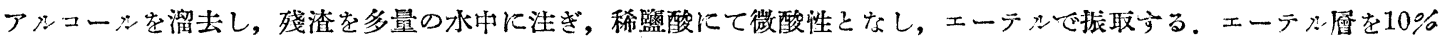

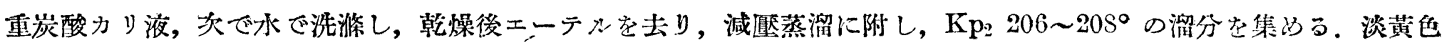
粘稠な油で過クロル鐵によつて葡啇酒赤色を呈する。

試料 $3.700 \mathrm{mg}: \mathrm{CO}_{2} 8.190 \mathrm{mg}, \mathrm{H}_{2} \mathrm{O} 2.150 \mathrm{mg}$.

$$
\mathrm{C}_{17} \mathrm{H}_{22} \mathrm{O}_{7} \text { 計算值 } \quad \mathrm{C} \quad 60.36, \quad \mathrm{H} \quad 6.51 \text {. 䁈驗值 } \quad \mathrm{C} \quad 60.37, \quad \mathrm{H} \quad 6.50 \text {. }
$$

\section{6) $\beta$-(3,5-Dimethoxybenzoyl)-propionsäure (VII)}

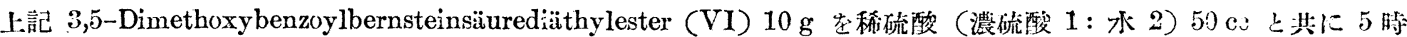

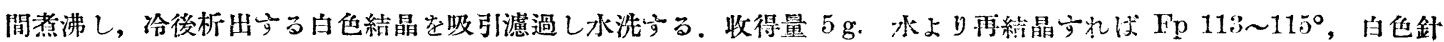
狀の結晶となる。

試料 $3.820 \mathrm{mg}: \mathrm{CO}_{2} 8.490 \mathrm{mg}, \mathrm{H}_{2} \mathrm{O} 1.950 \mathrm{mg}$.

$$
\mathrm{C}_{12} \mathrm{H}_{14} \mathrm{O}_{5} \text { 計算值 } \quad \mathrm{C} \quad 60.50, \quad \mathrm{H} \quad 5.88 \text {. 實驗值 } \quad \text { C } \quad 60.62, \quad \text { H } 5.71 \text {. }
$$

\section{Semicarbazon :}

常法に從ひ (VII) の Semicarbazon を作りメヌノールより數包再結晶すれば 169〜171。の゙發泡下に溶融する無 色針狀結晶となる。

試料 $5.010 \mathrm{mg}$ : $\mathrm{CO}_{2} 9.720 \mathrm{mg}, \mathrm{H}_{2} \mathrm{O} 2.580 \mathrm{mg}$.一試料 $2.070 \mathrm{mg}: \mathrm{N}_{2} 0.239 \mathrm{cc}\left(16^{\circ}, 771 \mathrm{~mm}\right)$.

$\begin{array}{llllllll}\mathrm{C}_{13} \mathrm{H}_{17} \mathrm{O}_{5} \mathrm{~N}_{3} & \text { 計算値 } & \mathrm{C} & 52.88, & \mathrm{H} & 5.76, & \mathrm{~N} & 14.24 . \\ & \text { 實驗值 } & \mathrm{C} & 52.91, & \mathrm{H} & 5.76, & \mathrm{~N} & 13.83 .\end{array}$




\section{7) $\gamma$-(3,5-Dimethoxyphenyl)-butyrolacton (VIII)}

$\beta$-(3,5-Dimethoxybenzoyl)-propionsïure (VII) を還元して $\gamma$-(3,5-Dimethoxyphenyl)-buttersïure を得る日的で

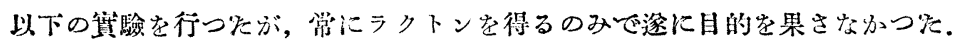

即 (VII) $10 \mathrm{~g}$ をClemmensen-Martin 法に從ひ亞鉛アマルガム $20 \mathrm{~g}$, 整酸 $35 \mathrm{cc}$, 水 $15 \mathrm{cc}$ 及トルォール $75 \mathrm{cc}$ の

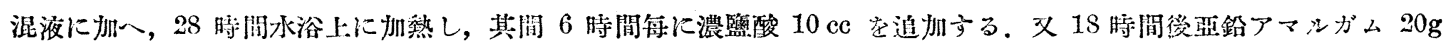

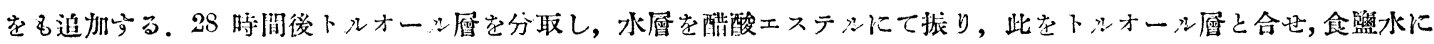

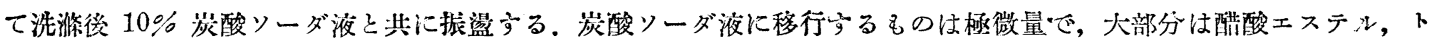

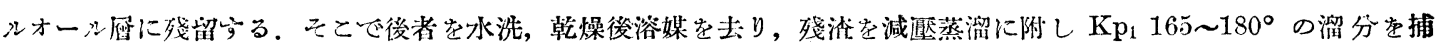

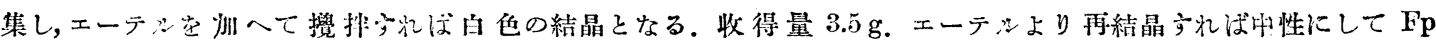

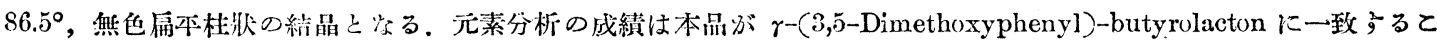

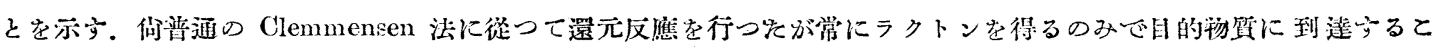
とが出來なかつマと.

試料 $3.990 \mathrm{mg}$ : $\mathrm{CO}_{2} 9.600 \mathrm{mg}, \mathrm{H}_{2} \mathrm{O} 2.175 \mathrm{mg}$.

$$
\mathrm{C}_{12} \mathrm{H}_{14} \mathrm{O}_{4} \text { 計算值 } \quad \mathrm{C} \quad 64.80, \quad \mathrm{H} \quad 6.30 \text {. 触羷值 } \quad \mathrm{C} \quad 65.04, \quad \text { H } 6.30 \text {. }
$$

\section{8) 4-Keto-6,7,8-trimethoxytetralin (IX)}

A 法: Mitter 及 De の方法によつて得 F F 1550 つ 4-Keto-6,7-dimethoxy-8-oxytetralin11) 7.8 g をアセトン

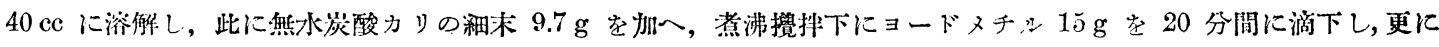

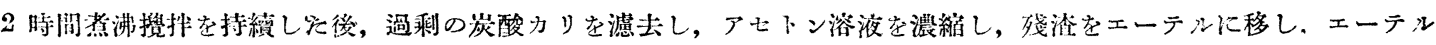

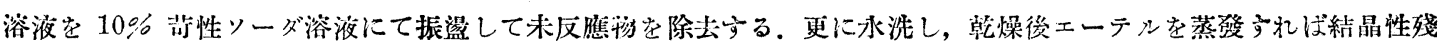

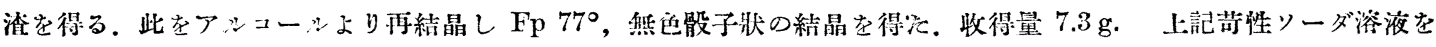
酸性にして Fp $155^{\circ}$ の原料 $0.5 \mathrm{~g}$ 迥收しで.

B 法：4-Keto-6,7-dimethoxy-8-oxytetralin $29.1 \mathrm{~g}$ を 20\% 些性ソーダ $105 \mathrm{~g}$ に溶解し， $50^{\circ}$ に於て鯢拌しつ

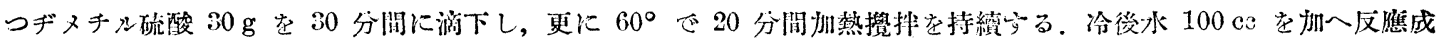

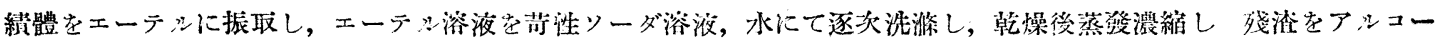

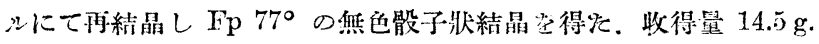

娬料 $3.175 \mathrm{mg}$ : $\mathrm{CO}_{2} 7.690 \mathrm{mg}, \mathrm{H}_{2} \mathrm{O} 1.815 \mathrm{mg}$.
$\mathrm{C}_{3} 3 \mathrm{H}_{16} \mathrm{O}_{4}$ 㻤算值
C 66.06, H 6.83 .
賽驗值
C 66.06,
H 6.40 .

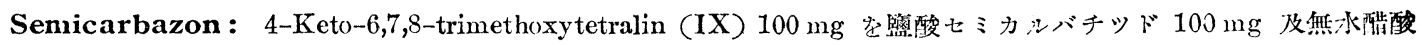

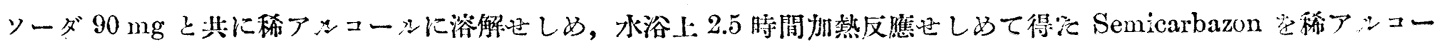
みより再結晶して, Fp $190^{\circ}$ 無色小針狀の結晶を得年。

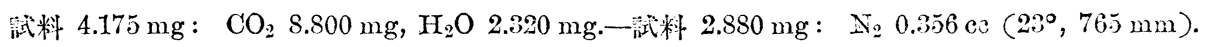

$$
\begin{array}{rccccccc}
\mathrm{C}_{14} \mathrm{H}_{19} \mathrm{O}_{4} \mathrm{~N}_{3} & \text { 計算値 } & \mathrm{C} & 57.30, & \mathrm{H} & 6.38, & \mathrm{~N} & 14.33 . \\
& \text { 触驗值 } & \mathrm{C} & 57.48, & \mathrm{H} & 6.22, & \mathrm{~N} & 14.35 .
\end{array}
$$

\section{9) 6,7,8-Trimethoxytetralin $(\mathrm{X})$}

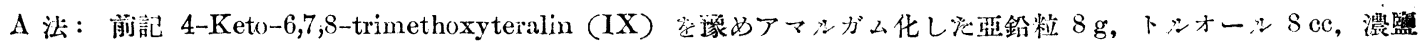

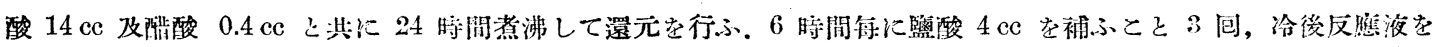

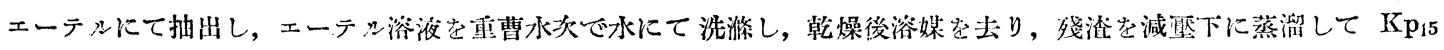

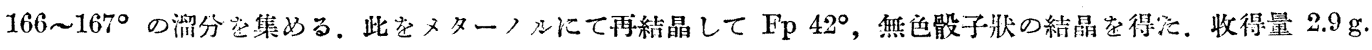

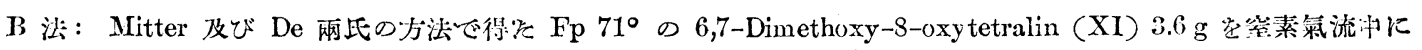

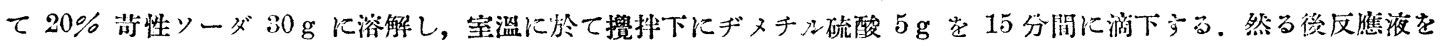

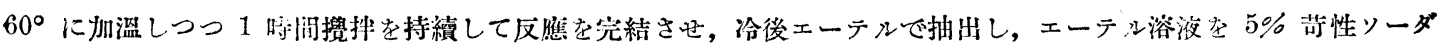

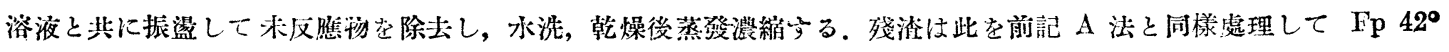

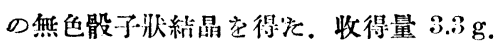


荀料 $4.085 \mathrm{mg}: \mathrm{CO}_{2} 10.505 \mathrm{mg}, \mathrm{H}_{2} \mathrm{O} 2.955 \mathrm{mg}$.
$\mathrm{C}_{13} \mathrm{H}_{18} \mathrm{O}_{3}$ 計算值
C 70.22,
H 8.17 .
筫驗值
C 70.14, H 8.18 .

\section{0） 6,7,8-Trimethoxytetralin の脫メトオキシル反應の試み}

A 法: 67,8-Trimethoxytetralin 8,6 g を無水アルコーュ $344 \mathrm{cc}$ に溶解し，沸騰下に金屬ナトリウム、34.4 g を約

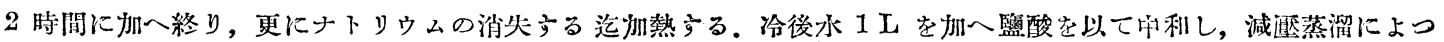

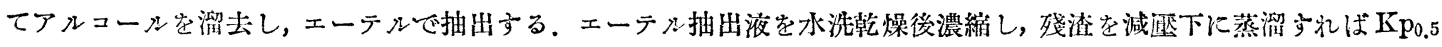

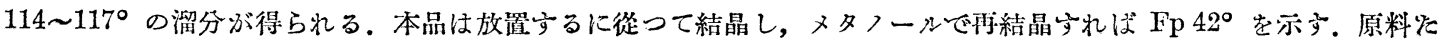
る 6,7,8-Trimethoxytetralin と混融するに融點の降下を示さ奴。回收量は $6.8 \mathrm{~g}$ て $79 \%$ に相賞うる。

B 法：A 法に於ける無水アルコールをイソアミルアルコールに代一高溫度に於て 6,7,8-Trmethoxytetralin の水 素還元を試み\%，然るに此場合には前記の如き原料包收を見なかつたが，又 6,8-Dimethoxytetralin も遂に得られな ぬつ\%.

11) 6,8-Dimethoxytetralin (XII)

4-Keto-6,7,8-trimethoxytetralin (IX) $7.3 \mathrm{~g}$ をイソアミルアルコール $300 \mathrm{cc}$ に溶解し，沸騰下に金屬ナトリウム

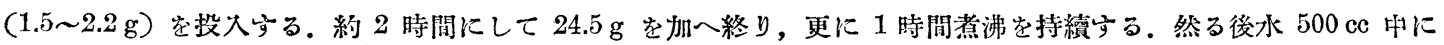
泩入し，析出するイソアミルアルコール層を分取し，水洗乾燥後減原下に濃縮し，更に分溜して $\mathrm{Kp}_{0.2} 105 \sim 115^{\circ}$ の 溜分を集める. 收得量 $2.6 \mathrm{~g}$.

G. Schroeter によれば本品は Fp 38.5〜39.5 とあるも，著者等が兹に得を物質は是を結晶に導き得なかつを。

試料 $4.635 \mathrm{mg}$ : $\mathrm{CO}_{2} 12.770 \mathrm{mg}, \mathrm{H}_{2} \mathrm{O} 3.610 \mathrm{mg}$.
$\mathrm{C}_{12} \mathrm{H}_{16} \mathrm{O}_{2}$ 計算值
C $74.95, \quad$ H 8.39 .
筫驗值
C 75.14, H 8.71 .

12) 6,8-Dioxytetralin $\left(\mathrm{XII}^{\prime}\right)$

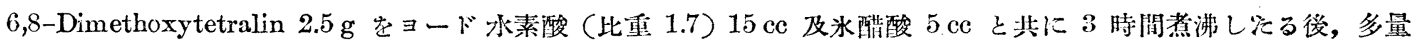

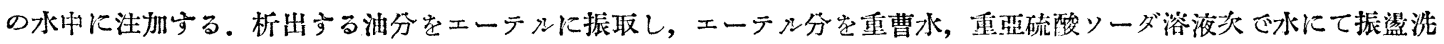

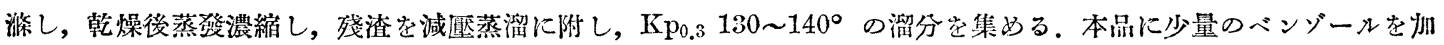

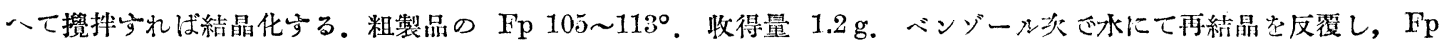
$121.5^{\circ}$ 無色微細鱗片狀の結晶を得を。收得:量 $0.7 \mathrm{~g}$.

試料 $3.745 \mathrm{mg}$ : $\mathrm{CO}_{2} 10.025 \mathrm{mg}, \mathrm{H}_{2} \mathrm{O} 2.495 \mathrm{mg}$.
$\mathrm{C}_{10} \mathrm{H}_{12} \mathrm{O}_{2}$ 計算值
C 73.13 , H 7.37 .
賽驗值 C 73.01, H 7.45 .

本品は Schroeter1)3) 法により 6,8-Diaminotetralin より得た 6,8-Dioxytetralin と混融を行ふも融點の變化なく同 一物なるととを確め注。

\section{3) 6,8-Diacetoxytetralin ( $\left.\mathrm{XII}^{\prime \prime}\right)$}

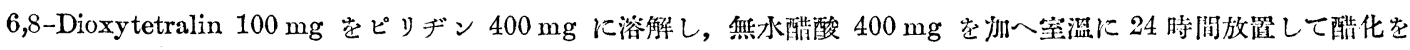
行ふ、常法に從つて醋化體を分離し $50 \%$ アッコールより再結晶して, Fp 42 祭色針狀の結晶を得炕。

試料 $4.010 \mathrm{mg}$ : $\mathrm{CO}_{2} 9.985 \mathrm{mg}, \mathrm{H}_{2} \mathrm{O} 2.315 \mathrm{mg}$.
$\mathrm{C}_{14} \mathrm{H}_{16} \mathrm{O}_{4}$ 計算值
C 67.71 ,
$\mathrm{H} \quad 6.50$.
筫驗值
C 67.91,
II 6.46 .

株式會社武田長兵街商店研觉部 (昭利 16 年 6 月 30 日受理)

\section{1.トドマツ酸 (Todomätusaure) の構造に就て}

百 瀨 勉

トドマツ (Abies sachalinensis Mast.) よりパルプ製造の際副生するテレビン油の高沸點部分より，土樆氏はは一種の 結晶酸 $\mathrm{C}_{15} \mathrm{H}_{24} \mathrm{O}_{3}$ Fp 58-58.5,$[\alpha]_{1}^{32.5}=+85.84^{\circ}$ を發見し、トドマッ酸 (Todomatusïure) と命名した.

土橋氏は本酸が天然にメチルエステルとして存在すること，本酸が容易にセミカルバッォンを生成なるからケトン

1) 土橋, 榛澤：日化 61, 1041 . 